\title{
Radiotherapy Bolus
}

National Cancer Institute

\section{Source}

National Cancer Institute. Radiotherapy Bolus. NCI Thesaurus. Code C112914.

A tissue-equivalent material placed in contact with the skin to increase the surface dose and/or compensate for missing tissue. A bolus can also be used to compensate for lack of scatter, such as near the extremities or the head during total-body irradiation. 